\title{
Validasi Metoda Analisa Kadar Logam Pb pada Rambut Karyawan SPBU jln. Juanda Kota Padang
}

\author{
Dyna Putri Mayaserli a,1, ${ }^{\text {, }}$, Renowati ${ }^{\text {a,2 }}$ \\ a STIKes Perintis Padang, Padang, 25173, Indonesia \\ ${ }^{1}$ dyna2205@yahoo.com *; ${ }^{2}$ renowati@yahoo.com; \\ * corresponding author
}

\section{ARTICLE INFO}

Article history

Received June 22, 2019

Revised September 08, 2019

Accepted September 08, 2019

Keywords

Validation

Plumbum

Method analysis

\section{ABSTRACT}

Development in the health sector is the achievement of optimal public health degrees. People who are often exposed to air pollution, one of them is a gas station officer, for example lead metal $(\mathrm{Pb})$. One of the objectives of this study was to determine differences in the cost $(P b)$ in the hair of gas station workers on Jl. Ir. Juanda Padang is based on the length of the working period by using an experimental type of research to analyze $\mathrm{Pb}$ metal on gas station employees. The population and sample of the study were 3 gas station employees' hair containing 3 people. The sampling technique is based on the length of work. The results of this study found that the longer the employee's working period the higher the $\mathrm{Pb}$ level in the employee's hair and the percentage recovery value for the method of wet destruction using $\mathrm{HNO}_{3}$ and $\mathrm{HClO}_{4}$ had an average recovery of $96.23 \%$ where the precision test was $4.01 \%$. It is recommended tha the next validation test use another method, namely dry destruction and review of parameters about age, place of birth date and lifestyle.

This is an open-access article under the CC-BY-SA license.

\section{Pendahuluan}

Perkembangan dalam bidang kesehatan dapat dilihat dari derajat kesehatan masyarakat yang optimal. Lingkungan merupakan bagian terbesar yang didalamnya terdapat manusia dan sumber daya alam yang tak terpisahkan, apabila lingkungan tersebut mengalami kerusakan ataupun pencemaran maka akan menjadi suatu tekanan yang paling berat. Pembangunan yang pesat di segala bidang selain memberikan dampak positif, juga memberikan dampak negatif. Dampak negatif yang sulit untuk dihindari adalah terjadinya pencemaran lingkungan, baik pencemaran air, pencemaran tanah, maupun pencemaran udara [1] yang banyak menimbulkan berbagai penyakit yang lambat laun dapat menimbulkan kematian, seperti penyakit diare, demam berdarah, kuning, pernapasan, penyakit kanker dan yang lainnya [2-4].

Pencemaran yang ditimbulkan oleh limbah ada bermacam-macam bentuk. Ada pencemaran berupa bau, warna, suara dana bahkan pemutusan mata rantai dari suatu tatanan lingkungan hidup atau penghancuran dan merusak suatu ekosistem yang terlibat didalamnya. Pencemaran yang dapat menghancurkan tatanan lingkungan hidup, biasanya berasal dari limbah yang sangat berbahaya dalam arti memiliki daya racuna (toksisitas) yang tinggi. Limbah yang sangat beracun pada umumnya merupakan limbah kimia. Senyawa kimia yang sangat beracun bagi organisme hidup dan manusia adalah senyawa kimia yang mempunyai bahan aktif dari logam berat, sebagai contoh adalah logam merkuria $(\mathrm{Hg})$, cadmium $(\mathrm{Cd})$, timbal $(\mathrm{Pb})$ dan chroma $(\mathrm{Cr})$, serta bahan kimia lainnya yang sulit didegradasi di alam dan sangat persisten misalnya pestisida, dioksin, dan lain-lain [5-6]. 
Rambut manusia dapat merekam unsur yang masuk ke dalam tubuh manusia melalui tiga pintu yaitu melalui makanan dan atau pencernaan, pernapasan dan kulit. Keberadaan dan konsentrasi unsur dalam rambut dapat merefleksikan keadaan/status kesehatan tubuh dimana seseorang tinggal dan bekerja. Dengan menganalisis unsur dalam rambut dapat diketahui apakah konsentrasi unsur tersebut kurang, cukup atau bahkan terlalu tinggi. Kelebihan melakukan analisis unsur dalam rambut jika dibandingkan dengan analisis unsur dalam darah atau urin adalah analisis unsur dalam rambut lebih mudah pelaksanaannya serta penanganan sampel lebih sederhana [7].

Orang yang sering terpapar oleh polusi udara salah satu diantaranya adalah petugas pom bensin. Diperkirakan emisi gas buang yang dikeluarkan dari kendaraan bermotor dapat menimbulkan kontaminasi terhadap tubuh para petugas pom bensin yang mengisi bahan bakar kendaraan. Pom bensin merupakan tempat untuk pengisian bahan bakar kendaraan. Dalam penggunaannya seharihari sering kali orang kurang waspada dan berhati-hati sehingga kemungkinan dapat timbul efek terhadap kesehatan. Apalagi jika bensin disalahagunakan, misalnya dengan sengaja menghirup uapnya untuk menimbulkan sensasi merasa senang atau 'fly'. Bensin dapat masuk ke dalam tubuh manusia melalui berbagai rute paparan, yang paling umum adalah melalui hidung atau terhirup. Petugas di pom bensin akan terpapar uap bensin lebih banyak dari pada orang yang sesekali mengisi bensin. Beberapa bahan kimia dalam bensin dapat menembus kulit dengan lebih mudah dari pada bahan kimia lainnya [8]

Penentuan tingkat pencemaran logam dapat ditentukan dengan pengambilan sampel darah maupun cuplikan rambut, karena rambut terpapar langsung oleh logam berat karena dalam tubuh manusia logam dalam bentuk anorganik dapat terdistribusi dalam jaringan lunak terutama ginjal dan hati. Kemudian akan mengalami redistribusi oleh darah ke dalam tulang, gigi dan rambut. Disamping itu cuplikan rambut mempunyai beberapa keunggulan karena lebih mencerminkan tingkat kontaminasi dalam jangka waktu yang cukup lama. Mengingat alasan tersebut rambut lebih banyak digunakan sebagai indikator akumulasi logam berat, selanjutnya rambut secara unik dapat digunakan untuk membedakan kontaminasi internal dan kontaminasi eksternal. Salah satu metode analisis yang dapat digunakan adalah metode Spektrometri Serapan Atom [9] dengan beberapa kelebihan antara lain cuplikan yang dibutuhkan relatif sedikit, mudah dan sederhana cara pengoperasiannya.

Dari latar belakang di atas penulis tertarik untuk mengetahui kadar logam berat Timbal $(\mathrm{Pb})$ pada rambut petugas yang ada di SPBU di daerah Purus Padang, Tujuan dari penelitian ini adalah untuk mengetahui perbedaan kadar $\mathrm{Pb}$ (timbal) dalam rambut pekerja SPBU di Jl. Ir. Juanda berdasarkan lama masa kerja dan untuk mengetahui validitas metode analisis logam $\mathrm{Pb}$ dalam sampel rambut dengan menggunakan SSA jika menggunakan metode destruksi basah $\mathrm{HNO}_{3}, \mathrm{HCLO}_{4}$.

\section{Metodologi Penelitian}

Peralatan yang digunakan pada penelitian ini adalah Spektrofotometer Serapan Atom, hot plate dan peralatan gelas. Bahan yang digunakan adalah rambut, standar $\mathrm{Pb}, \mathrm{HNO}_{3}, \mathrm{HClO}_{4}$, aquades.

\subsection{Pembuatan larutan standar}

Pembuatan larutan standar menurut $[10,11]$ yaitu :

a. Pembuatan Larutan Induk $\mathrm{Pb} 1000 \mathrm{ppm}$

Timbang 1,5985 gram $\mathrm{Pb}\left(\mathrm{NO}_{3}\right)_{2}$ kemudian diencerkan dengan $\mathrm{HNO}_{3} 1 \mathrm{M}$ dalam labu ukur 1 L hingga tanda batas.

b. Pembuatan Larutan Standar Baku Pb 100 ppm

Pipet $10 \mathrm{~mL}$ larutan induk $\mathrm{Pb} 1000$ ppm ke dalam labu ukur $100 \mathrm{~mL}$, kemudian diencerkan dengan $\mathrm{HNO}_{3} 1 \mathrm{M}$ hingga tanda batas.

c. Pembuatan Larutan Standar Baku Pb 10 ppm

Pipet 10 mL larutan induk $\mathrm{Pb} 100$ ppm ke dalam labu ukur $100 \mathrm{~mL}$, kemudian diencerkankan dengan $\mathrm{HNO}_{3} 1 \mathrm{M}$ hingga tanda batas.

d. Pembuatan deret standar 0,$0 ; 0,2 ; 0,4 ; 0,6 ; 0,8 ; 1,0 \mathrm{ppm}$

Pipet $0,2,4,6,8,10 \mathrm{~mL}$ larutan induk $10 \mathrm{ppm}$ ke dalam labu ukur $100 \mathrm{~mL}$, kemudian diencerkan dengan $\mathrm{HNO}_{3} 1 \mathrm{M}$ hingga tanda batas. 


\subsection{Destruksi Basah}

Metode destruksi basah dengan menggunakan asam $\mathrm{HNO}_{3}$ dan $\mathrm{HClO}_{4}$ [10]: potong segmen rambut sekitar 5 sampai $10 \mathrm{~mm}$ panjang dan berat $2 \mathrm{mg}$. Menimbang sampel rambut dan dicuci dengan air deionisasi pada shaker mekanis kemudian direbus selama 15 menit dan didestruksi dengan campuran 1:5 $\mathrm{HClO}_{4}: \mathrm{HNO}_{3}$ hingga membentuk cairan hampir jernih. Mengencerkan sampel dalam labu ukur $50 \mathrm{~mL}$ dengan air deionisasi hingga tanda batas.

Tabel 1. Kriteria sampel yang diambil

\begin{tabular}{cccc}
\hline No & Lama Masa Kerja & Jumlah Sampel (Laki-Laki) & Jumlah Karyawan \\
\hline 1 & $1-4$ th & 1 & 3 \\
2 & $5-8$ th & 1 & 3 \\
3 & $9-12$ th & 1 & 2 \\
\hline
\end{tabular}

\subsection{Penentuan Konsentrasi Logam Pb pada Rambut Karyawan SPBU dengan SSA}

Analisa ini menggunakan SSA dengan lampu katoda $\mathrm{Pb}$ dan Panjang gelombang 283,3 $\mathrm{nm}$. Karena pada panjang gelombang tersebut terjadi proses penyerapan secara maksimal sehingga kadar logam $\mathrm{Pb}$ yang terdeteksi lebis sempurna. Selanjutnya set zero alat dengan menggunakan larutan blanko, ukur absorban larutan standar $\mathrm{Pb}$ dari konsentrasi rendah ke konsentrasi tinggi. Sampel yang sudah didestruksi hingga didapatkan kadar logam Pb pada sampel [10].

\subsection{Uji Akurasi (ketepatan)}

Uji ini dilakukan dengan cara menambahkan larutan baku pembanding ( $\mathrm{Pb} \mathrm{0,6} \mathrm{ppm)} \mathrm{ke} \mathrm{dalam}$ sampel yang akan diperiksa sebelum didestruksi, kemudian dilakukan uji blanko (tanpa penambahan larutan baku standar). Masing-masing sampel kemudian didestruksi dengan metode destruksi basah menggunakan $\mathrm{HNO}_{3}$ dan $\mathrm{HCLO}_{4}$ dan diukur menggunakan SSA pada Panjang gelombang $480 \mathrm{~nm}$.

\subsection{Uji Presisi}

Metode uji presisi dilakukan secara repatibilitas atau keterulangan dilakukan dalam kondisi yang sama dalam interval waktu yang singkat, yaitu dengan mengukur larutan sampel metode destruksi basah menggunakan $\mathrm{HNO}_{3}$ dan $\mathrm{HCLO}_{4}$ dengan 3 kali ulang pada hari yang sama, kemudian data hasil absorbs dihitung simpang bakunya [11].

\subsection{Uji Linieritas}

Uji ini dilakukan dengan membuat kurva kalibrasi standar dengan beberapa macam konsentrasi standar $\mathrm{Pb}$ yang dimulai dari larutan tanpa $\mathrm{Pb}$. Kemudian dilanjutkan dengan mengukur standar $\mathrm{Pb}$ 0,$2 ; 0,4 ; 0,6 ; 0,8 ;$ dan 1 ppm. Setelah itu didapatkan harga "r" [11].

\subsection{Uji Limit Deteksi (LoD) Dan Uji Limit Kuintitasi (LoQ)}

Menurut Ervina (2003) uji LoD dan LoQ dapat diukur dengan konsentrasi standar yang paling rendah yang dapat terdeteksi absorbansinya dengan rumus :

LoD dapat dihitung dengan rumus :

LoD $=3 \times$ SD

LoQ dapat dihitung dengan rumus :

$$
\text { LoQ }=10 \times \text { SD }
$$

\section{Hasil dan Pembahasan}

\subsection{Kadar Pb dalam Rambut dengan menggunakan metoda destruksi basah}

Pada penelitian ini digunakan sampel rambut karyawan SPBU dengan berat sampel sebanyak 2 gr. Sampel tersebut didestruksi basah dengan menggunakan $\mathrm{HCLO}_{4}$ dan $\mathrm{HNO}_{3}$ diukur dengan SSA pada panjang gelombang $283,3 \mathrm{~nm}$. Fungsi dari destruksi adalah untuk memutuskan ikatan antara senyawa organik dengan logam yang akan dianalisis. Logam yang dianalisis adalah $\mathrm{Pb}$, kadar $\mathrm{Pb}$ dalam rambut merupakan salah satu indikator terkumulasinya logam $\mathrm{Pb}$ dalam tubuh. Salah satu 
syarat analisis logam dengan menggunakan SSA adalah sampel harus berupa larutan. Pelarut yang dapat digunakan untuk destruksi basah antara lain asam nitrat, asam sulfat, asam perklorat, dan asam klorida. Untuk itu dilakukan analisis $\mathrm{Pb}$ dalam rambut dengan menggunakan metode destruksi basah dengan campuran asam yang berbeda $[8,11]$.

Tabel 2. $\quad$ Kadar Logam $\mathrm{Pb}$ Pada Rambut

\begin{tabular}{ccc}
\hline No & Lama Masa Kerja & Kadar Rata-Rata Pb mg/g \\
\hline 1 & $1-4$ th & 0,3561 \\
2 & $5-8$ th & 0,5918 \\
3 & $9-12$ th & 0,8175 \\
\hline
\end{tabular}

Berdasarkan tabel 2 didapatkan kadar Pb dalam rambut karyawan SPBU. Semakin lama masa kerjanya semakin tinggi kadar $\mathrm{Pb}$ dalam rambut karyawan tersebut, karena lebih lama terpapar $\mathrm{Pb}$. Dari data diatas didapatkan hasil paling tinggi adalah $0,8175 \mathrm{mg} / \mathrm{g}$ dengan lama masa kerja 9-12 tahun.

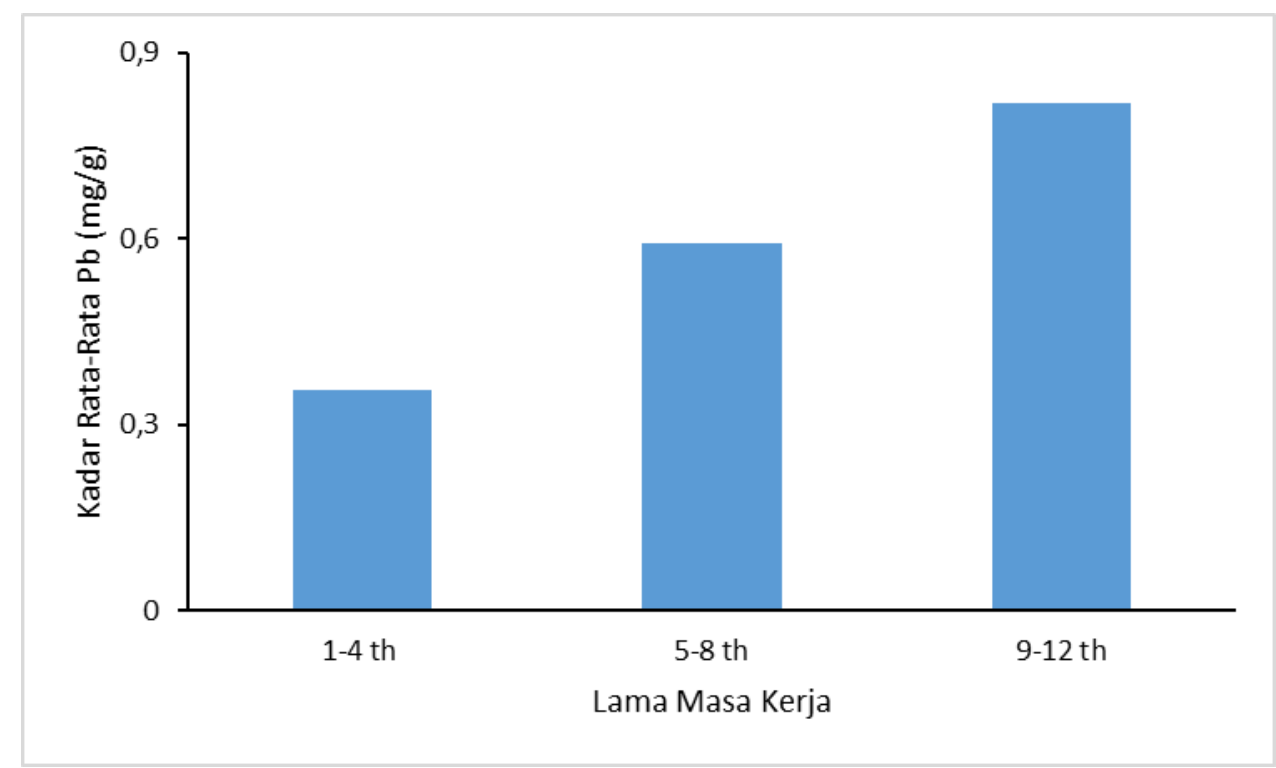

Gambar 1. Kurva Kadar Logam Pb Pada Rambut

Pada grafik diatas bisa dilihat berdasarkan lama masa kerja karyawan SPBU bahwa semakin lama masa kerja karyawan SPBU semakin tinggi pula kadar logam $\mathrm{Pb}$. Timbal $(\mathrm{Pb})$ dapat masuk melalui pernapasan, makanan, dan minuman. Accidental poisoning seperti termakannya senyawa timbal dalam konsentrasi tinggi dapat mengakibatkan gastrointestinal akut, rasa logam pada mulut, muntah, sakit perut, dan diare. Logam $\mathrm{Pb}$ dapat mempengaruhi sistem saraf, intelegensia, dan pertumbuhan. Efek logam $\mathrm{Pb}$ pada kesehatan manusia akan menimbulkan kerusakan otak, kejang bahkan kematian.

\subsection{Uji Akurasi (Ketepatan)}

Akurasi adalah ukuran yang menunjukan derajat kedekatan hasil analisa dengan kadar yang sebenarnya. Terkadang masalah dalam menentukan akurasi adalah ketidaktahuan terhadap nilai yang sebenarnya. Akurasi juga dapat diketahui dengan melakukan uji perolehan kembali (recovery) hasil uji ini akurasi dapat dinyatakan sebagai persen perolehan kembali (recovery) analit yang ditambahkan pada sampel. Akurasi dapat dilihat dari nilai recovery spike yaitu dengan cara menambahkan sejumlah analit (standar) yang diketahui konsentrasinya ke dalam contoh. Rata-rata dari nilai sebenarnya harus mendekati $100 \%$, karena nilai kisaran persentase recovery disaratkan, yaitu $100 \% \pm 15$ persentase recovery yang memenuhi persyaratan maka metode ini akurat [12]. 
Tabel 3. Hasil Uji Recovery Logam Pb pada Rambut

\begin{tabular}{cccccc}
\hline $\begin{array}{c}\text { Sampel } \\
(\boldsymbol{\mu g} / \mathbf{m l})\end{array}$ & $\begin{array}{c}\text { Volume Sampel } \\
(\mathbf{m l})\end{array}$ & $\begin{array}{c}\text { Spike Pb } \\
(\boldsymbol{\mu} \mathbf{g})\end{array}$ & $\begin{array}{c}\text { Kadar Pb } \\
\text { Teoritis }(\boldsymbol{\mu g})\end{array}$ & $\begin{array}{c}\text { Kadar Pb } \\
\text { Analisis }(\boldsymbol{\mu g})\end{array}$ & $\begin{array}{c}\text { Recovery } \\
(\boldsymbol{\%})\end{array}$ \\
\hline $\mathrm{A}$ & 10 & - & - & 6,43 & - \\
$\mathrm{A}+2 \mathrm{ml} \mathrm{Pb} \mathrm{0.6}$ & 10 & 1,2 & 7,63 & 6,82 & 89,38 \\
$\mathrm{~A}+2 \mathrm{ml} \mathrm{Pb} \mathrm{0.6}$ & 10 & 1,2 & 7,63 & 6,68 & 87,5 \\
$\mathrm{~A}+2 \mathrm{ml} \mathrm{Pb} \mathrm{0.6}$ & 10 & 1,2 & 7,63 & 8,53 & 111,8 \\
& \multicolumn{7}{r}{ Rata-rata destruksi } \\
\end{tabular}

Berdasarkan tabel 3 diperoleh nilai persentase recovery untuk metode dekstruksi basah dengan menggunakan $\mathrm{HNO}_{3}$ dan $\mathrm{HClO}_{4}$ mempunyai rata-rata recovery $96,23 \%$ dengan demikian metode destruksi ini sudah baik karena rata-rata recovery diperoleh $96,23 \%$ yang berada pada nilai kisaran persentase recovery yang disyaratkan, yaitu pada rentang $100 \% \pm 15$ dengan nilai yang lebih mendekati $100 \%$. Rentang tersebut dianggap baik karena menunjukan bahwa metoda tersebut mempunyai ketepatan yang baik dalam menunjukan tingkat kesesuaian nilai rata-rata dari suatu pengukuran yang sebanding dengan nilai sebenarnya dapat dikatakan pada proses destruksi tidak ada $\mathrm{Pb}$ yang hilang dan dapat dianggap akurat [12].

\subsection{Uji Presisi}

Uji presisi dilakukan dengan metode repitabilitas, yaitu pengulangan dilakukan dalam kondisi yang sama dalam interval waktu yang singkat. Kondisi sama ini dapat diartikan dengan penggunaan laboratorium yang sama, metode analisis yang sama, dan pereaksi serta peralatan yang sama. Metode repitabilitas dianggap lebih efisien karena waktu yang digunakan lebih singkat serta dengan proses lebih mudah. Presisi yang menggambarkan kesalahan acak dari suatu pengukuran dinyatakan dalam bentuk persentase Relative Standard Deviation (\% RSD) [13].

Tabel 4. Hasil Uji Presisi Logam Pb pada Rambut

\begin{tabular}{lcccc}
\hline \multirow{3}{*}{ Destruksi } & \multicolumn{3}{c}{ Konsentrasi $(\boldsymbol{\mu g} / \mathbf{k g})$} & \% RSD \\
\cline { 2 - 4 } & I & II & III & \multirow{2}{*}{4,01} \\
\cline { 2 - 4 } & 0,6929 & 0,6903 & 0,6222 & \\
\hline
\end{tabular}

Berdasarkan tabel 4 dapat dilihat nilai persentasea metode destruksi sebesar 4,01\%. Nilai yang diperoleh masih berada pada rintangan yang disyaratkan. Konsentrasi $\mathrm{Pb}$ hasil analisis adalah $<5 \%$ sehingga penelitian ini termasuk ke dalam kategori trace analysis $[14,15]$.

\subsection{Uji Limit of Detection (LoD), Limit of Quantitation (LoQ) dan uji Liniearitas}

Uji Limit of Detection (LoD) adalah jumlah terkecil analit dalam sampel dapat dideteksi yang masih memberikan respon signifikan dibandingkan dengan blangko. Batas deteksi merupakan parameter uji batas dan batas kuantitasi merupakan parameter pada analisis renik diartikan sebagai kuantitas terkecil analit dalam sampel yang masih dapat memenuhi kriteria cermat dan seksama Limit of Quantitation (LoQ) adalah kosentrasi analit terendah dalam sampel yang dapat ditentukan dengan presisi dan akurasi yang dapat diterima pada kondisi operasional metode yang digunakan. LoQ merupakan suatu kompromi antara kosentrasi dengan presisi dan akurasi yang dipersyaratkan jika kosentrasi LoQ menurun maka presisi juga menurun. Jika presisi tinggi dipersyaratkan, maka kosentrasi LoQ lebih tinggi harus dilaporkan LoQ adalah konsentrasi atau jumlah terendah dari analit yang masih dapat ditentukan dan memenuhi kriteria akurasi dan presisi Limit of Kuantitasi disebut limit pelaporan [16]. 
Tabel 5. Uji Limit of Detection (LoD), Limit of Quantitation (LoQ)

\begin{tabular}{|c|c|c|c|c|c|}
\hline No & $\begin{array}{c}\text { Konsentrasi } \\
\text { (ppm) }\end{array}$ & Absorban & $\mathbf{Y i}$ & $\mathbf{Y}-\mathbf{Y i}$ & $(\mathbf{Y}-\mathbf{Y i})^{2}$ \\
\hline 1 & 0.200 & 0.0082 & -0.01376 & 0.02196 & 0.000482242 \\
\hline 2 & 0.400 & 0.0163 & -0.00072 & 0.01702 & 0.00028968 \\
\hline 3 & 0.600 & 0.0235 & 0.01232 & 0,01118 & 0.000124992 \\
\hline 4 & 0.800 & 0.031 & 0.02536 & 0.00564 & 3.18096E-05 \\
\hline \multirow[t]{5}{*}{5} & 1.000 & 0.0382 & 0.03840 & -0.0002 & 4E-08 \\
\hline & & Jumlah & & & 0,000928764 \\
\hline & & $\mathrm{SDX} / \mathrm{Y}$ & & & 0,0268 \\
\hline & & LoD & & & 0,0804 \\
\hline & & LoQ & & & 0,2680 \\
\hline
\end{tabular}

Berdasarkan tabel 5 hasil perhitungan nilai Limit of Deteksia (LoD) yang merupakan penjumlahan antara nilai rata-rata konsentrasi terkecil ditambah dengan hasil perkalian tiga kali standar deviasi $\mathrm{x} / \mathrm{y}$, sehingga didapatkan limit deteksi sebesar $0,0804 \mathrm{mg} / \mathrm{L}$. Sedangkan hasil perhitungan nilai limit kuantitasi (LoQ) jika konsentrasi LoQ menurun maka presisi juga menurun dengan hasil perkalian sepuluh kali standar deviasi $\mathrm{x} / \mathrm{y}$, sehingga didapatkan limit kuantitasi sebesar $0,2680 \mathrm{mg} / \mathrm{L}[16]$.

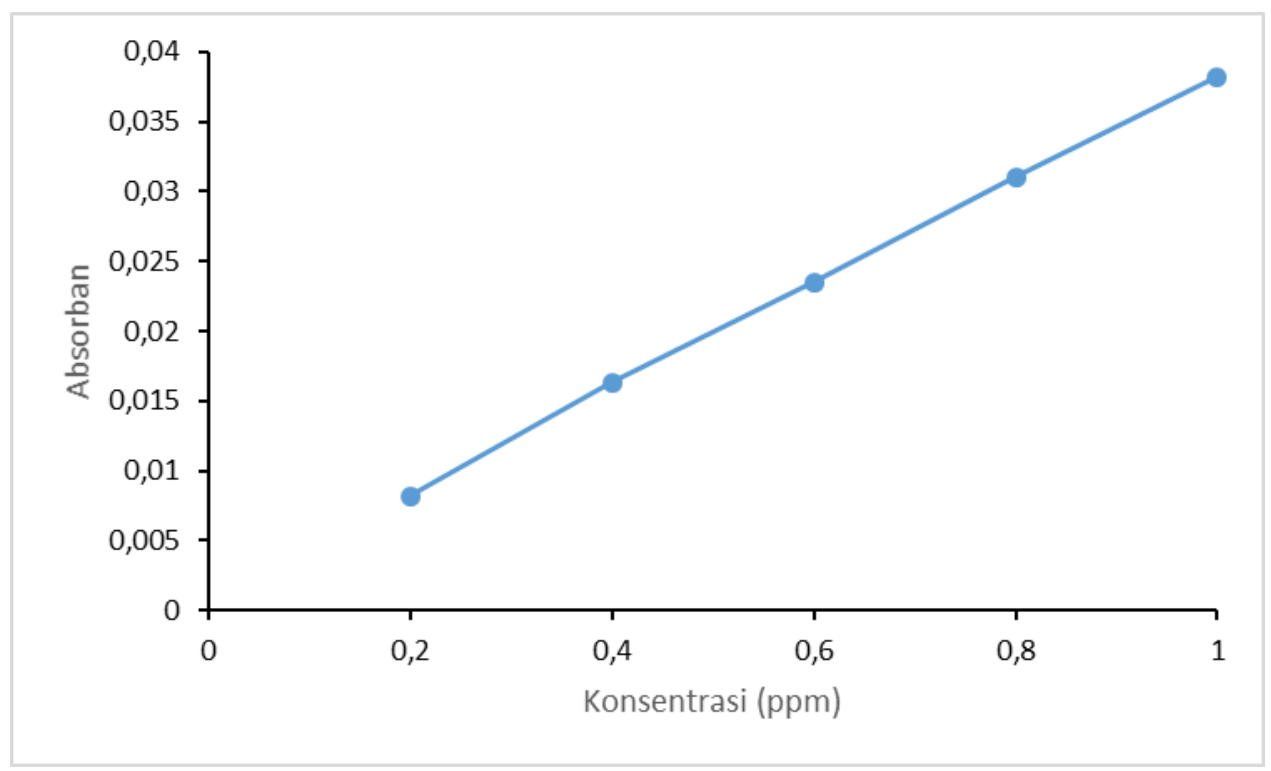

Gambar 2. Kurva kalibrasi larutan standar timbal $(\mathrm{Pb})$

Berdasarkan grafik diatas hasil tersebut dapat dilihat pada gambar kurva kalibrasi larutan standar timbal $(\mathrm{Pb})$ yang menunjukkan titik konsentrasi. Dalam kurva kalibrasi menunjukkan hasil yang linear, namun pengukuran harus mencapai limit kuantitasi agar pengukuran lebih akurat. Dengan demikian sesuai dengan gambar kurva kalibrsi larutan standar timbal, hasil pengukuran metode destruksi dikatakan lebih baik dengan konsentrasi yang melebihi LoQ sehingga memberikan hasil dengan akurasi yang tinggi.

\section{Kesimpulan}

Kadar Pb pada karyawan SPBU dimana paling tinggi terdapat pada 9-12 tahun yaitu 0,1657 ppm dan yang paling rendah terdapat pada 1- 4 tahun yaitu 0,0713. Semakin lama masa kerja karyawan di SPBU maka kadar $\mathrm{Pb}$ pada rambut semakin meningkat. Hasil uji recovery metode ini dengan menggunakan pengoksidasi $\mathrm{HNO}_{3}$ dan $\mathrm{HClO}_{4}$ adalah 96,23\% dan presisi 4,01\%. Hasil ini dapat 
digolongkan dalam kategori teliti bahwa metoda destruksi ini dapat dipercaya atau lebih valid untuk analisis $\mathrm{Pb}$ dalam Rambut dengan SSA.

\section{Pustaka}

[1]. Fardiaz. S. 1992, Polusi Air dan udara, Kanisius, Yogyakarta.

[2]. Darmono. 1995. Logam dalam Sistem Biologi Makhluk Hidup. Penerbit Universitas Indonesia. Jakarta

[3]. Darmono. 1995. Lingkungan Hidup Dana Pencemaran. UI-Press. Jakarta.

[4]. Librawati, T.P. 2005. Analisis Cemaran Pb pada Bawang Daun (Allium fitstulosum L) di daerah Dieng Wonosobo. Universitas Jendral Sudirman: Fakultas Biologi

[5]. Palar, H.1994. Pencemaran dan Toksikologi Logam Berat. Jakarta : Rineka Cipta.

[6]. Palar, H. 2004. Pencemaran dan Toksikologi Logam Berat. Rineka cipta. Jakarta

[7]. Hamid, R. Z. 1991.Dampak Polutan Plumbun (Timbal) terhadap Lingkungan Hidup dan Kesehatan Manusia. Jurnal Lingkungan dan Pembangunan, jakarta.

[8]. Saenia, M. S. 1997. Penentuan Tingkat Pencemaran Logam Berat dengan Analisis Rambut. Orasi Ilmiah. Bogor

[9]. Supriyanto, C, Samin \& zainul, K. 2007. Analisis cemaran logam berat $\mathrm{Pb}, \mathrm{Cu}$, dan Cd pada ikan air tawar dengan metode spektrometri nyala serapan atom (SSA). Yogyakarta

[10]. Pettrucci, R. H. 1982. General Chemistry (3rd ed). New York: Mc. Millan Publishing Co.

[11]. Harvey, David. 2000. Modern Analitycal Chemistry. The McGraw-Hill Companies. USA.

[12]. Sumardi. 2002. Validasi Metode Pengujian. Jakarta: Pusat Standardisasi dan Akreditasi Sekretariat Jendral Depertemen Pertanian

[13]. Harmita. 2004. Petunjuk Pelaksanaan Validasi Metode dan Cara Perhitungannya. Departemen Farmasi FMIPA-UI :Jakarta.

[14]. Suwirma, S. S., S.; Thamsil, L. (1988). Distribusi Logam Berat Hg, Pb, Cd, Cr, Cu, dan $\mathrm{Zn}$ dalam Tubuh Ikan. Majalah Batan

[15]. Sukirno \& Murniasih, S. 2009. Analisis Unsur Fe, Ca, Ti, Ba, Ce, Zr dan La dalam Sedimen Laut di Semenanjung Muria dengan Metode XRF. Prosiding Pusat Teknologi Akselerator dan Proses Bahan. Jakarta: LIPI

[16]. Harmita. 2004. Petunjuk Pelaksanaan Validasi Metode dan Cara Perhitungannya. Departemen Farmasi FMIPA-UI :Jakarta. 